\title{
A common Salmonella Enteritidis sequence type from poultry and human gastroenteritis in Ibagué, Colombia
}

\author{
Luz Clemencia Fandiño, Noel Verjan-García ${ }^{1,2}$ \\ ${ }^{1}$ Grupo de Investigación en Avicultura, Universidad del Tolima, Ibagué, Colombia \\ ${ }^{2}$ Grupo de Investigación en Inmunobiología y Patogénesis, Universidad del Tolima, Ibagué, \\ Colombia
}

Introduction: Salmonella Enteritidis is a major cause of human salmonellosis in the world, with contaminated eggs and raw chicken meat as the main routes of infection. The main Salmonella spp. serovars circulating in laying hen farms, the surface of eggs, and in raw chicken carcasses have been identified in lbagué, Colombia. However, it is unknown whether those serovars are responsible for human gastroenteritis.

Objective: To evaluate the genetic relationship between gastroenteritis and Salmonella Enteritidis isolates from poultry and humans using multilocus sequence typing (MLST). Materials and methods: Salmonella spp. was isolated from clinical cases of gastroenteritis $(n=110)$. Antibiotic susceptibility tests, followed by serotyping and MLST were conducted and $S$. Enteritidis was compared to those from laying hen farms and marketed eggs. Results: Ten isolates of Salmonella spp. were obtained from the stools of people with gastroenteritis. The prevalence of Salmonella spp. in human stools was $9.09 \%$, and $S$. Enteritidis $(n=4), S$. Typhymurium $(n=2), S$. Newport $(n=1), S$. Uganda $(n=1), S$. Grupensis $(n=1)$, and $S$. Braenderup $(n=1)$ were the main serotypes. MLST indicated that a common $S$. Enteritidis sequence type (ST11) was present in all three sources and showed the same antibiotic resistance pattern.

Conclusion: Salmonella Enteritidis ST11 constitutes a link between consumption and manipulation of contaminated eggs and human gastroenteritis in Ibagué. Additional studies would be required to establish if other Salmonella serovars isolated from raw chicken meat are also associated with human gastroenteritis.

Keywords: Salmonella; poultry; multilocus sequence typing; serogroup; gastroenteritis.

Received: $28 / 09 / 17$

Accepted: $30 / 07 / 18$

Published: $21 / 08 / 18$

\section{Citation:}

Fandiño L, Verjan-García N. A common Salmonella Enteritidis sequence type from poultry and human gastroenteritis in lbagué, Colombia. Biomédica. 2019;39(Supl.1):50-62

https://doi.org/10.7705/biomedica.v39i1.4155

Corresponding author:

Noel Verjan-García, Departamento de Salud Animal, Facultad de Medicina Veterinaria, Universidad del Tolima, Altos de Santa Helena, Ibagué, Colombia Telephone: (578) 2771212 nverjang@ut.edu.co

Author contributions:

Both authors contributed to the research and the drafting of the manuscript.

\section{Funding:}

This research was funded by grants from the Oficina Central de Investigaciones de la Universidad del Tolima to Noel Verjan-García (projects $\mathrm{N}^{\circ} 780213$ and 460113)

Conflict of interest

The authors reported no potential conflicts of interest.

\section{Un tipo de secuencia común de Salmonella Enteritidis de origen aviar y de humano} con gastroenteritis en Ibagué, Colombia

Introducción. Salmonella Enteritidis es una de las mayores causas de salmonelosis en el mundo; los huevos contaminados y la carne de pollo cruda son sus principales fuentes de infección. En lbagué, Colombia, se han identificado los principales serovares que circulan en granjas, superficies de huevos y canales de pollo, pero se desconoce si esos serovares son responsables de la gastroenteritis.

Objetivo. Evaluar la relación genética entre los aislamientos de Salmonella Enteritidis de aves de corral y de humanos con la gastroenteritis mediante tipificación de multiloci de secuencias (Multilocus Sequence Typing, MLST).

Materiales y métodos. Se aisló Salmonella spp. de casos clínicos de gastroenteritis $(n=110)$. Se hizo la prueba de sensibilidad antibiótica, así como la serotipificación y la tipificación mediante MLST, y se comparó $S$. Enteritidis de humanos con la hallada en granjas de gallinas ponedoras y en huevo comercializado $(n=6)$.

Resultados. Se aislaron 10 cepas de Salmonella spp. a partir de heces de humanos con gastroenteritis. Se obtuvo una prevalencia de Salmonella spp. de 9,09\%, y se identificaron los serotipos $S$. Enteritidis $(n=4), S$. Typhymurium $(n=2), S$. Newport $(n=1), S$. Grupensis $(n=1), S$. Uganda $(n=1)$ y $S$. Braenderup presentes en pacientes con gastroenteritis. Mediante la MLST, se comprobó que un tipo de secuencia común (ST11) de S. Enteritidis estuvo presente en todas las tres fuentes y presentó el mismo patrón de resistencia antibiótica.

Conclusión. Salmonella Enteritidis ST11 constituye un vínculo entre el consumo y la manipulación de huevos contaminados, y la gastroenteritis en humanos en lbagué. Se requieren estudios complementarios para conocer si otros serovares de Salmonella aislados de carne de pollo cruda también se asocian con la gastroenteritis en humanos.

Palabras clave: Salmonella, aves de corral, tipificación de secuencias multilocus, serogrupo, gastroenteritis. 
Salmonellosis is a widely distributed food-borne disease caused by subspecies I of Salmonella enterica. Subspecies I groups over 1,547 serovars that are pathogenic to humans and animals $(1,2)$.

Non-typhoidal Salmonella usually causes self-limiting gastroenteritis and under certain conditions, it may cause invasive extra-intestinal infections ( $S$. Typhimurium, $S$. Enteritidis, $S$. Dublin, and $S$. Heidelberg, among others), whereas typhoidal Salmonella (S. Typhi and S. Paratyphi A, B, and C) causes enteric fever (3). Non-typhoidal Salmonella infection may progress to a lifethreatening disease when the bacteria reach the bloodstream, particularly in young children, the elderly, and immunocompromised people (4).

Salmonella Enteritidis and $S$. Typhimurium are responsible for the majority of clinical cases of human salmonellosis worldwide (5-7). Those serovars are mostly transmitted through the consumption and manipulation of contaminated food, such as eggs and raw chicken meat $(8,9)$.

Non-typhoidal Salmonella was estimated to be responsible for about 80.3 million cases of food-borne gastroenteritis and 155,000 deaths each year in the world (10). In the United States, non-typhoidal Salmonella may cause up to 1 million cases of disease, 19,586 hospitalizations, and 378 deaths annually $(11,12)$. Non-typhoidal Salmonella also prevalent in other developed countries including Canada, where S. Infantis caused 110 clinical cases between 2015 and 2016 (13).In the United Kindom, S. Enteritidis (33.4\%) and S. Typhimurium (21.4\%) were the main serovars isolated from 799 fecal specimens during October, 2016 (14). Despite the decreasing trend of human salmonellosis cases in the European Union since 2008 (15), human cases of $S$. Enteritidis MLVA profile 2-9-7-3-2 increased in the Netherlands, Belgium, Denmark, Norway, Sweden, the United Kingdom, and other European countries, where eggs originating in Poland were identified as the vehicle of infection (16).

Salmonellosis in Colombia may also have a high prevalence. However, the disease is not properly notified or reported to the health-care centers, which usually lack the appropriate laboratories for correct identification and depend on a centralized laboratory at the Instituto Nacional de Salud in Bogotá to obtain complete identification. Thus, the impact of the bacteria on public health is not accurately known in many regions of the country.

The Instituto Nacional de Salud reported a total of 10,381 cases of foodborne illnesses during 2015 and a similar number during 2016 of which only $15 \%$ were confirmed by laboratory tests. The Institute also reported 7,219 Salmonella isolates from clinical cases, with S. Typhimurium (33.7\%), S. Enteritidis (28.6\%), and $S$. Typhi (9.2\%) being the most prevalent serotypes (17).

In the Tolima region, preliminary epidemiological studies have established the presence of Salmonella in different segments of the poultry industry reporting $S$. Enteritidis and $S$. Shannon in laying hen farms (18), $S$. Enteritidis in eggshells surfaces at the market place (19), and a total of 14 different Salmonella serovars present in chicken carcasses sold at stores and supermarkets in the city of lbagué (20) that included S. Paratyphi B, S. Hvittingfoss, S. Muenster, S. Typhimurium, S. Newport, S. Heidelberg, S. Braenderup, and $S$. Kalina, among others, but not $S$. Enteritidis. Among those serovars, $S$. Paratyphi B and $S$. Heidelberg were found as the most prevalent in broiler farms in the regions of Santander and Cundinamarca (21). 
Although those studies were useful to increase the awareness about the risk of Salmonella in poultry producers, the genetic relationship among those poultry isolates and the Salmonella causing gastroenteritis in humans has not been addressed. In addition, the absence of a causal relationship between Salmonella and the consumption or manipulation of poultry products has impeded the implementation of more rigorous diagnostic and surveillance programs to prevent the infection by this bacterium.

Given the discriminatory power of molecular tools, this study was designed to evaluate the genetic relationship between $S$. Enteritidis isolates from poultry and from humans with gastroenteritis in the city of lbague by using multilocus sequence typing (MLST), a highly discriminative technique used for microbial subtyping in epidemiological investigations, population biology, and studies on the evolution of pathogenicity-related traits of bacteria $(22,23)$.

\section{Materials and methods}

\section{Study design}

We conducted an observational cross-sectional study between August and December, 2015, to establish the preliminary prevalence of Salmonella spp. in stool samples from clinical cases of patients with gastroenteritis that were admitted to local health care centers in Ibagué (department of Tolima), Colombia. For the purpose of this investigation, the physicians agreed to share the clinical samples with the Facultad de Medicina Veterinaria $y$ Zootecnia at the Universidad del Tolima.

The sample size was calculated by the formula described by Thrusfield (24) with a 95\% confidence level, 5\% error, and expected prevalence of $5 \%$ as no systematic studies on Salmonella causing diarrhea in humans in the Tolima region were found. The calculated sample size was 73 and we collected 110 stool samples. The Instituto Nacional de Salud had reported that Salmonella spp. had been isolated in 18 of 87 biologic samples during week 52 with an average of 199 cases per week and a total of 10,381 human cases from 895 foodborne outbreaks during 2015 (17). Based on this information, the sample size was considered sufficient to establish the preliminary prevalence of Salmonella in the city.

\section{Biological material}

The sampling included two health care centers where we collected 110 stool samples for Salmonella isolation. Each fecal sample was stored in aseptic plastic bottles at the health care center and then transported in ice $\left(<4{ }^{\circ} \mathrm{C}\right)$ to the Laboratorio de Diagnóstico Veterinario at Universidad del Tolima and processed within two hours. In addition, three $S$. Enteritidis (UTS. Enteritidis 13001-13003) isolates obtained from the eggshell surface of eggs sold in stores and supermarkets (19), as well as another three isolated from crushed eggshells (UTS. Enteritidis 14048-14050) in laying farms (18) were also included in the study.

\section{Isolation of Salmonella from human stool samples}

For the isolation of Salmonella spp. we followed the Instituto Nacional de Salud protocol and the standard international guidelines from ISO 6579:2002/ Amd1:2007. Stool samples (swabs) were briefly seeded directly in MüllerKauffmann tetrathionate broth ${ }^{\mathrm{TM}}$ (Merck KGaA, Darmstadt, Germany) and incubated at $37^{\circ} \mathrm{C}$; a second aliquot was inoculated in Rappaport Vassiliadis 
broth $^{\mathrm{TM}}$ (Merck) and incubated at $42^{\circ} \mathrm{C}$ for 18 hours. Later, bacterial colonies were seeded in the highly selective media Xylose Lysine Tergitol 4 (XLT4) agar $^{\mathrm{TM}}$ (Merck) and the low selective media SS (Salmonella-Shigella) and McConkey agar ${ }^{\mathrm{TM}}$ (Merck) and incubated at $37^{\circ} \mathrm{C}$ for $18-24$ hours.

Subsequently, compatible colonies were seeded in chromogenic Rambach agar $^{\mathrm{TM}}$ (Merck) and confirmed as Salmonella spp. by using the miniaturized biochemical BBL Crystal test ${ }^{\mathrm{TM}}$ (E/NF) for non-fermenter enteric bacteria. Salmonella isolates were also confirmed by agglutination with Poli A-I + $\mathrm{Vi}{ }^{\mathrm{TM}}$ (Difco 222641, Becton Dickinson \& Co, Sparks, MD, USA) antibodies. Positive controls included S. Typhimurium ATCC 14028, and S. Enteritidis ATCC 13076.

\section{Serotyping of Salmonella spp. isolates}

Salmonella spp. isolates were serotyped by using the White-KauffmanLe Minor scheme, which identifies the presence of specific somatic $(O)$ and flagellar $(\mathrm{H})$ antigens with commercial antisera (Difco, Becton Dickinson and Co., Sparks, MD, USA). Serotyping was performed based on the antigenic description by Grimont and Weill (2007) (1) and the nomenclature described by Tindall, et al. (25), and by the Judicial Commission of the International Committee on Systematics of Prokaryotes. The procedure was carried out at the Instituto Colombiano de Agricultura.

\section{Antibiotic susceptibility tests}

The Kirby-Bauer method (agar-disc diffusion) was used to assess the susceptibility of Salmonella to chloramphenicol (CHL, $30 \mu \mathrm{g})$, florfenicol (FFC, $30 \mu \mathrm{g}$ ), enrofloxacin (ENR, $5 \mu \mathrm{g}$ ), norfloxacin (NOR, $10 \mu \mathrm{g}$ ), fosfomycin (FOF, $50 \mu \mathrm{g}$ ), and streptomycin (STR, $10 \mu \mathrm{g}$ ), which are antibiotics commonly used in veterinary medicine but not included in the automated microdilution Phoenix ${ }^{\text {TM }}$ (Becton Dickinson, Sparks, MD, USA) method. A bacterial suspension in Mueller-Hinton II agar $^{\mathrm{TM}}$ (BBL) was calibrated according to the $0.5 \mathrm{McF}$ arland scale of turbidity and the bacterial growth inhibition at $37^{\circ} \mathrm{C}$ for 18 to 24 hours was evaluated according to the guidelines of the Clinical and Laboratory Standards Institute (26).

Salmonella isolates were also subjected to an antimicrobial microdilution susceptibility test by using the BD Phoenix NMIC/ID-94 panels ${ }^{\mathrm{TM}}$ (Becton Dickinson, Sparks, MD, USA) and the categories established by the Clinical and Laboratory Standards Institute (26).

The antibiotics used in this assay and their concentration were amikacin (AMK, 8-32 $\mu \mathrm{g} / \mathrm{ml}$ ), amoxicillin-clavulanate (AMC, 4/2-16/8 $\mu \mathrm{g} / \mathrm{ml}$ ), ampicillin (AMP, 4-16 $\mu \mathrm{g} / \mathrm{ml}$ ), cefepime (FEP, 1-16 $\mu \mathrm{g} / \mathrm{ml}$ ), cefoxitin (FOX, 4-16 $\mu \mathrm{g} / \mathrm{ml}$ ), ceftazidime (CAZ, 1-16 $\mu \mathrm{g} / \mathrm{ml})$, ceftriaxone (CRO, 1-32 $\mu \mathrm{g} / \mathrm{ml})$, cefuroxime (CXM, 4-16 $\mu \mathrm{g} / \mathrm{ml}$ ), ciprofloxacin (CIP, 0.5-2 $\mu \mathrm{g} / \mathrm{ml}$ ), ertapenem (ETP, 0.25-4 $\mu \mathrm{g} / \mathrm{ml})$, gentamicin (GEN, 2-8 $\mu \mathrm{g} / \mathrm{ml}$ ), imipenem (IPM, 1-8 $\mu \mathrm{g} / \mathrm{ml}$ ), levofloxacin (LVX, 1-4 $\mu \mathrm{g} / \mathrm{ml}$ ), meropenem (MEM, 1-8 $\mu \mathrm{g} / \mathrm{ml}$ ), piperacillin-tazobactam (TZP, 4/4- 64/4 $\mu \mathrm{g} / \mathrm{ml}$ ), tigecycline (TGC, $1-4 \mu \mathrm{g} / \mathrm{ml}$ ), and trimethoprimsulfamethoxazole (SXT, 1/19 - 4/76).

Salmonella isolates with absolute resistance were the only ones considered as resistant strains. Multi-drug resistant strains of Salmonella were defined as those showing phenotype resistance to at least three classes of antibiotics. Escherichia coli ATCC 25922 was used as the reference strain. 


\section{Polymerase chain reaction}

The molecular analysis was performed at the Laboratorio de Immunología y Biología Molecular of the Universidad del Tolima. Genomic DNA was extracted from each Salmonella isolate by the phenol:chloroform:isoamyl alcohol (25:24:1) method (27). All nine Salmonella isolates were subjected to PCR amplification of a $284 \mathrm{bp}$ fragment of the invA gene for Salmonella genus confirmation using the forward 5'-GTG AAA TTA TCG CCA CGT TCG GGC AA-3' and reverse 5'-TCA TCG CAC CGT CAA AGG AAC C-3' primers ${ }^{\mathrm{TM}}$ (Invitrogen, Thermo Fisher Scientific Inc.) described by Rahn, et al. (28).

The PCR reaction was performed in a total volume of $25 \mu$ using the AccuPrime Taq DNA polymerase system ${ }^{\mathrm{TM}}$ (Invitrogen Life Technologies), containing $2.5 \mu \mathrm{MgCl}_{2}(50 \mathrm{mM}), 2.5 \mu \mathrm{l} 10 \times$ buffer, $0.8 \mu \mathrm{l}$ of each primer $(10$ $\mu \mathrm{M}), 2,5 \mu \mathrm{l}$ of dNTP $(8 \mathrm{mM}), 0.5 \mu \mathrm{l}$ Taq DNA polymerase, and $1 \mu \mathrm{l}$ of DNA (200 ng) template. Amplification was carried out in a T-100 (Bio-Rad) thermal cycler with the following program: An initial denaturation step at $95^{\circ} \mathrm{C}$ for five minutes, followed by 35 cycles of denaturation at $94^{\circ} \mathrm{C}$ for one minute, annealing at $55^{\circ} \mathrm{C}$ for 30 seconds, an extension at $68^{\circ} \mathrm{C}$ for 30 seconds, and a final extension step at $68^{\circ} \mathrm{C}$ for seven minutes. The PCR products were mixed with $2 \mu \mathrm{l}$ of $10 \times$ loading buffer and then resolved by electrophoresis on $2 \%$ agarose gel with 100 bp DNA ladder ${ }^{\mathrm{TM}}$ (Invitrogen). The gel was stained with ethidium bromide and visualized under the UV light by using an ENDURO GDSTM (Labnet International, Inc.) gel documentation system.

\section{Multilocus sequence typing of Salmonella Enteritidis isolates}

Three $S$. Enteritidis strains isolated from human stools, three $S$. Enteritidis strains isolated from eggs sold at stores and supermarkets (19), and another three isolated from crushed eggshells from laying hen farms were randomly selected and a total of nine $S$. Enteritidis were subjected to the Achtman scheme of PCR amplification and sequencing of seven housekeeping genes (29).

The gene was analyzed by encoding the aspartokinase + homoserine dehydrogenase (thrA), phosphoribosyl aminoimidazole carboxylase (purE), alpha ketoglutarate dehydrogenase (sucA), histidinol dehydrogenase (hisD), chorismate synthase (aroC), uroporphyrinogen III cosynthase (hemD,) and DNA polymerase III beta subunit (dnaN) with the primers described on the MLST website (http://mlst.warwick.ac.uk/mlst/).

The PCR reaction was done as described previously under the following conditions: An initial denaturation step at $94{ }^{\circ} \mathrm{C}$ for three minutes, followed by 35 cycles at $94^{\circ} \mathrm{C}$ for one minute, $55^{\circ} \mathrm{C}$ for one minute, and $72{ }^{\circ} \mathrm{C}$ for one minute, with a final extension step at $72^{\circ} \mathrm{C}$ for five minutes. PCR products were purified using a DNA purification kit ${ }^{\mathrm{TM}}$ (Invitrogen, Thermo Fisher Scientific Inc.) and subsequently sequenced (Macrogen Inc., Korea) in both directions using the Sanger sequencing method. The DNA sequences were assembled using Genetyx, version 7.0, software and submitted to the online Salmonella MLST database of the University of Warwick to obtain allelic profiles and the specific sequence type of each isolate.

\section{Nucleotide sequence analysis}

The DNA sequence data of seven housekeeping genes from Salmonella were compared individually with those in the GenBank (www.ncbi.nlm.nih.gov) database using the BLASTN (version 2.5.1+) software (30) of the National Center for Biotechnology Information. Multi-alignment of nucleotide sequences 
was carried out with BioEdit, version 7.0.5, and Genetyx, version 7, and the phylogenetic analysis was performed with the Molecular Evolutionary Genetics Analysis (MEGA) version 6 (31) using the maximum likelihood method.

\section{Results}

\section{Isolation and serovars of Salmonella spp. from human stool samples}

A total of 10 Salmonella spp. were isolated from 110 human stool samples collected in Ibagué. We found a Salmonella prevalence of $9.09 \%$ in patients with gastroenteritis. The biochemical and agglutination tests with polyclonal anti-Vi-A antibodies and amplification of $284 \mathrm{bp}$ of the invA gene by PCR confirmed the identification of Salmonella genus. From these 10 Salmonella isolates, six different serovars of Salmonella enterica were identified. Salmonella Enteritidis (4/10) and $S$. Typhimurium (2/10) were the predominant serovars, followed by $S$. Newport, $S$. Braenderup, $S$. Uganda, and $S$. Grupensis, each one with one isolate (table 1).

\section{Antibiotic susceptibility test}

All Salmonella isolated from humans with gastroenteritis showed resistance to two classes of antibiotics: Aminoglycosides (amikacin and gentamicin), and cephalosporin (cefoxitin and cefuroxime). Only one $S$. Typhimurium was found to be multi-drug resistant to at least nine antibiotics including amikacin, ampicillin, cefoxitin, cefuroxime, gentamicin, trimethoprim/ sulfamethoxazole, streptomycin, chloramphenicol, and florfenicol.

Table 1. Serovars and sequence types of Salmonella Enteritidis isolated from poultry and humans with gastroenteritis in Ibagué, Colombia

\begin{tabular}{|c|c|c|c|c|c|c|}
\hline Salmonella code & Source & Sample & Serovar & Allele & $\begin{array}{l}\text { Sequence } \\
\text { type }\end{array}$ & $\begin{array}{l}\text { Sequence } \\
\text { type complex }\end{array}$ \\
\hline UTS. Enteritidis 13001 & Laying hen farm & Crushed eggshell & S. Enteritidis & $\begin{array}{l}\text { aroC } 5 \text {, dnaN 2, hemD 3, HisD7, } \\
\text { purE 6, sucA 6, thrA653 }\end{array}$ & ST3172 & Unknown \\
\hline UTS. Enteritidis 13002 & Laying hen farm & Crushed eggshell & S. Enteritidis & $\begin{array}{l}\text { aroC } 5 \text {, dnaN 2, hemD } 3, \text { HisD7, } \\
\text { purE } 6 \text {, sucA } 6 \text {, thrA11 }\end{array}$ & ST11 & 4 \\
\hline UTS. Enteritidis 13003 & Laying hen farm & Crushed eggshell & S. Enteritidis & $\begin{array}{l}\text { aroC } 5 \text {, dnaN 2, hemD 3, HisD7, } \\
\text { purE 6, sucA 6, thrA11 }\end{array}$ & ST11 & 4 \\
\hline UTS. Enteritidis 14048 & Wet market & Egg shell surface wash & S. Enteritidis & $\begin{array}{l}\text { aroC } 5 \text {, dnaN 2, hemD 3, HisD7, } \\
\text { purE 6, sucA 6, thrA11 }\end{array}$ & ST11 & 4 \\
\hline UTS. Enteritidis 14049 & Wet market & Egg shell surface wash & S. Enteritidis & $\begin{array}{l}\text { aroC } 5 \text {, dnaN 2, hemD 3, HisD7, } \\
\text { purE } 6 \text {, sucA } 6 \text {, thrA11 }\end{array}$ & ST11 & 4 \\
\hline UTS. Enteritidis 14050 & Wet market & Egg shell surface wash & S. Enteritidis & $\begin{array}{l}\text { aroC } 5 \text {, dnaN } 584 \text {, hemD } 3 \text {, } \\
\text { HisD7, purE } 6 \text {, sucA } 6 \text {, thrA11 }\end{array}$ & ST3233 & Unknown \\
\hline UTS. Enteritidis 15001 & Human & Stool sample & S. Enteritidis & $\begin{array}{l}\text { aroC } 5 \text {, dnaN 2, hemD } 3, \text { HisD7, } \\
\text { purE } 6 \text {, sucA } 6 \text {, thrA11 }\end{array}$ & ST11 & 4 \\
\hline UTS. Enteritidis 15002 & Human & Stool sample & S. Enteritidis & $\begin{array}{l}\text { aroC } 5 \text {, dnaN 2, hemD } 3 \text {, HisD7, } \\
\text { purE } 6 \text {, sucA 6, thrA11 }\end{array}$ & ST11 & 4 \\
\hline UTS. Enteritidis 15003 & Human & Stool sample & S. Enteritidis & $\begin{array}{l}\operatorname{aroC} 5 \text {, dnaN 2, hemD 3, HisD7, } \\
\text { purE 6, sucA 6, thrA11 }\end{array}$ & ST11 & 4 \\
\hline UTS. Enteritidis 15004 & Human & Stool sample & S. Enteritidis & $U$ & $U$ & U \\
\hline UTST-15020 & Human & Stool sample & S. Typhimurium & $U$ & $U$ & U \\
\hline UTSN-15021 & Human & Stool sample & S. Newport & $U$ & $U$ & $U$ \\
\hline UTSB-15022 & Human & Stool sample & S. Typhimurium & $U$ & $U$ & $U$ \\
\hline UTSB-15023 & Human & Stool sample & S. Braenderup & $U$ & $U$ & $U$ \\
\hline UTSU-15024 & Human & Stool sample & S. Uganda & $U$ & $U$ & $U$ \\
\hline UTSG-15025 & Human & Stool sample & S. Grupensis & $U$ & $U$ & $U$ \\
\hline
\end{tabular}

U: Undetermined

${ }^{*}$ Crushed eggshell

${ }^{* *}$ Eggs collected at the market place 
On the other hand, all Salmonella isolates were susceptible to amoxicillin/ clavulanate, cefepime, ceftazidime, ceftriaxone, ciprofloxacin, ertapenem, imipenem, levofloxacin, meropenem, piperacillin/tazobactam, and tigecycline. Additionally, all S. Enteritidis, S. Braenderup, S. Newport, S. Grupensis, $S$. Uganda, and one $S$. Typhimurium isolate were also susceptible to streptomycin, chloramphenicol, florfenicol, enrofloxacin, norfloxacin and phosphomycin tested by the Kirby-Bauer method.

\section{Multilocus sequence typing}

Nine randomly selected isolates of $S$. Enteritidis from both poultry and humans were subjected to MLST analysis. The identified sequence types were ST3172, ST11, and ST3233 with ST11 being the most frequent sequence type present in laying hen farms (2/3), on the surface of commercialized eggs (2/3) and in human stool samples (3/3) (table 1). Variations in the sequences of the genes thrA and dnaN appeared to be responsible for the emergence of the sequence types ST3172 and ST3233 whereas consistency in the DNA sequence of the aroC gene allowed further phylogenetic analyses.

\section{Phylogenetic analysis}

The aroC gene from all seven housekeeping genes was selected for further phylogenetic analysis. The phylogenetic tree obtained with the aroC gene sequences from Salmonella isolated in Tolima and those deposited in GenBank showed a singular cluster (cluster I, figure 1) composed of $S$. Enteritidis from human stool samples $(n=3), S$. Enteritidis from eggshell surfaces $(n=3)$, and one isolate obtained from laying hen farms (UTS. Enteritidis 13001) that branched from one of the $S$. Enteritidis UTS. Enteritidis 13003 isolates obtained from laying hen farms. A second cluster was composed of $S$. Enteritidis isolated from laying hen farms (UTS. Enteritidis 13002) clustered together with S. enterica FORC_019, S. Paratyphi A, and $S$. Typhimurium LT2 reference strains (cluster II, figure 1), whereas the other reference strains formed an independent cluster (figure 1).

\section{Discussion}

Salmonella Enteritidis and S. Typhimurium are the predominant cause of nontyphoidal Salmonella in humans worldwide and this situation may be the same in many regions in Colombia where very limited epidemiological studies have addressed the potential link between poultry and human salmonellosis and no routine microbiological isolation tests are conducted due to the lack of appropriate laboratory facilities. Although such epidemiological information to support the sources of human isolates is still lacking in Colombia, to our knowledge this is the first report describing a common S. Enteritidis sequence type ST11 with an identical antibiotic resistance pattern in poultry, especially commercial eggs, and stools from humans with gastroenteritis, which suggests that commercial eggs play a role in the transmission of non-typhoidal salmonellosis in Ibagué.

Six different serovars of non-typhoidal S. enterica were isolated from 10 positive stool samples of people with gastroenteritis in Ibagué, Colombia (table 1). The serovars $S$. Newport, $S$. Braenderup, and $S$. Typhymurium were also isolated from raw chicken carcasses marketed in Ibagué (20), whereas $S$. Uganda and S. Grupensis were novel serovars identified in the Tolima region. In addition, most of these serovars had been isolated from poultry in the region of Cundinamarca (32). 


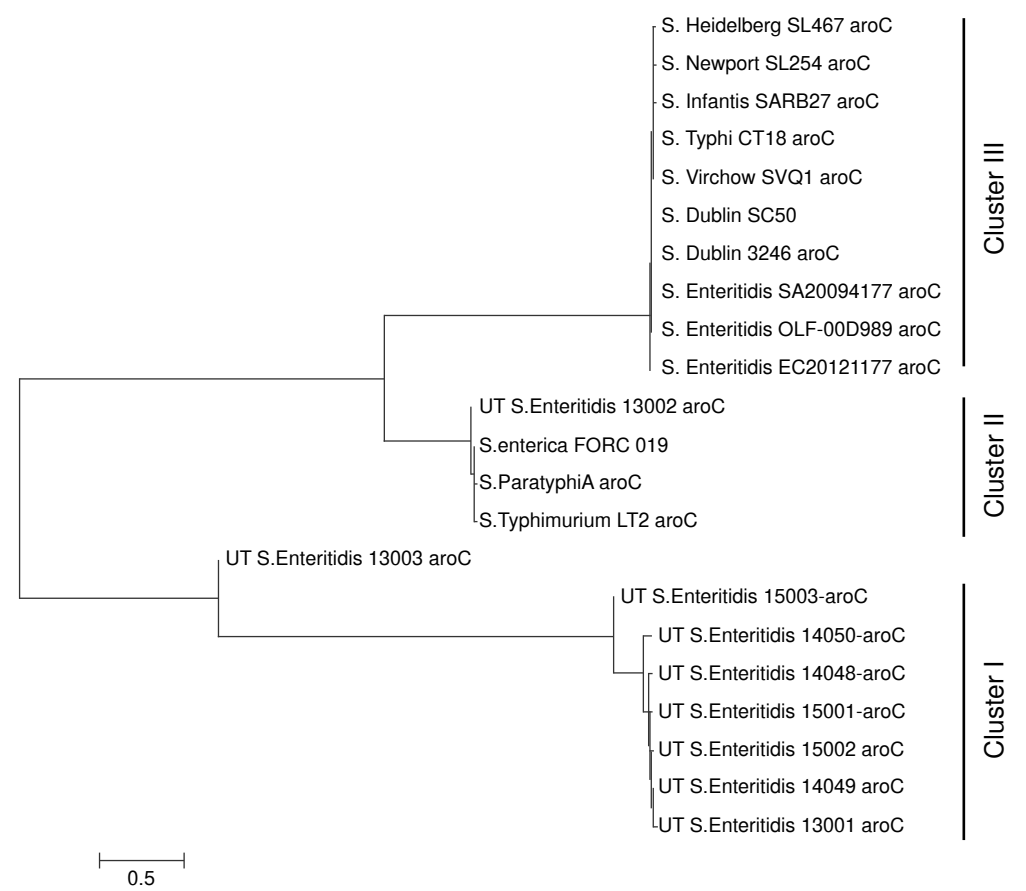

Figure 1. Phylogenetic tree of the chorismate synthase $(\mathrm{aroC})$ gene from Salmonella enterica serovar Enteritidis isolated from humans with gastroenteritis and poultry, and other reference strains. The evolutionary history was inferred by using the maximum likelihood method based on the TamuraNei model (1). The tree with the highest log likelihood (-5805.4149) is shown drawn to scale with branch lengths measured in the number of substitutions per site. Nucleotide sequences from various Salmonella strains were aligned and the tree image was constructed by using the Molecular Evolutionary Genetic Analyses, MEGA6 (2).

The accession numbers are the following: Salmonella enterica strain FORC_019, CP012396.1; S. Enteritidis strain OLF-00D989 87-1, CP011942.1; S. Enteritidis str. SA20094177, CP007468.2; S. Enteritidis str. EC29121177, CP007333.2; S. Heidelberg str. SL476, CP001120.1; S. Newport str. SL254, NC_011080.1; S. Infantis str. SARB27, NZ_AFYI00000000.1; S. Typhi str. CT18, AL513382.1; S. Virchow str. SVQ1, NZ_AZMP00000000.1; S. Dublin str. 3246, CM001151.1; S. Paratyphi A, CP000026.1; S. Typhimurium LT2, NC_003197.1. The human isolates obtained from clinical cases of gastroenteritis, laying hen farms, and egg shells from the wet market in the Tolima region are those coded UTS. Enteritidis 15001-15003, UTS. Enteritidis 13001-13003, and UTS. Enteritidis 1404814050, respectively.

Despite differences in geographical distribution of isolates causing gastroenteritis in humans, to some extent our results are similar to those reported in Bangladesh where five different serovars were isolated from poultry and stool samples of human cases of gastroenteritis including $S$. Paratyphi B var Java $(n=16), S$. Kentucky $(n=7), S$. Enteritidis $(n=6), S$. Virchow $(n=4)$, and $S$. Weltevreden $(n=1)$, and one genotype of $S$. Enteritidis ST11 was indistinguishable from poultry and humans by PFGE and MLST (33).

Our results suggest that clinical cases of gastroenteritis in humans in Ibagué could be caused by a variety of Salmonella spp. serovars and that $S$. Enteritidis ST11, a common sequence type reported worldwide, and $S$. Typhimurium could have a predominant role as they were isolated from shell eggs and raw chicken meat, respectively $(18,20)$.

In our previous studies we reported that $S$. Enteritidis was present in laying hen farms and in the surface of eggs, but not in chicken meat marketed in stores and supermarkets of lbagué (20). Thus, in this study we compared 
the predominant serovar of Salmonella in stool samples from gastroenteritis patients with poultry isolates. The serovars $S$. Newport, $S$. Braenderup, and $S$. Typhymurium found in stools from humans with gastroenteritis were commonly isolated from raw chicken carcasses marketed in this city (20). Nevertheless, S. Uganda, and S. Grupensis were novel serovars identified in the Tolima region and perhaps in the country (Ministerio de la Protección Social, 2011). Salmonella Braenderup was previously identified from the liver of laying hens in Colombia by using DNA hybridization (34). Further studies are needed to assess the relationships between serovars causing gastroenteritis in humans and chicken meat sold in this city.

In spite of the lack of relatedness in space and time between $S$. Enteritidis isolates from laying hen farms (year-2013), commercial shell eggs (year-2014), and clinical isolates (year-2015), S. Enteritidis from each source shared the same allelic profile and, therefore, the ST. Additionally, all S. Enteritidis showed a common antibiotic susceptibility pattern to aminoglycosides and cephalosporins. The phylogenetic analyses using the aroC gene sequence supported this relationship and indicated that human and shell egg isolates of $S$. Enteritidis are indistinguishable and that they formed a single cluster that appeared to have evolved from a common ancestor present in laying hen farms (figure 1). Circulation and transmission of clones of $S$. Enteritidis with similar PFGE genomic profiles and limited diversity that were isolated from food of animal origin, retail stores or different sampling years were reported in Argentina (35). A lack of specific patterns that could be associated with the source or year of isolation was reported in $S$. Enteritidis isolated from food $(n=61)$, chickens $(n=60)$, and humans ( $n=67$ ) during a 24-year period in Brazil using MLVA typing (36).

In the United States, intensive epidemiologic and laboratory investigations identified shell eggs as the major vehicle for $S$. Enteritidis infection in humans and established that internal contamination of eggs occurs by transovarian transmission of $S$. Enteritidis in the laying hen (8). Salmonella Enteritidis also appear to play a major role in egg contamination in the United Kingdom (37). Therefore, it was not unexpected to find a common genotype in poultry and human isolates in the Tolima region. In this sense, the evidence provided by this study may be useful to health care centers and public health authorities to increase the education on the risks created by Salmonella when poultry products are not properly manipulated or cooked before consumption.

The commercialization of dirty eggs in stores and supermarkets that can easily reach consumers' hands is indeed common in this city. The reason for this might be that laying hen farms predominantly use floor and conventional cage rearing systems in egg producing rather than furnished cages, which are more appropriate for egg production since the use of floor and conventional cages was found to be a risk factor for $S$. Enteritidis contamination of eggs (38). Furthermore, the results of this study may also point to a lack of appropriate cleaning and disinfection protocols for eggs before selling and the need for a more rigorous quality control and surveillance program for Salmonella in the Tolima region by poultry producers and health authorities, respectively.

In this study, S. Enteritidis ST11 was identified as the common sequence type circulating in laying hen farms, egg shell surfaces and stools from humans with gastroenteritis in Ibagué. Salmonella Enteritidis is known to cause human diseases with pandemic proportions (39). Salmonella Enteritidis ST11 was identified as a stable lineage and highly clonal ST isolated from humans $(n=27)$, bovines ( $n=1)$, liquid eggs $(n=1)$, and eggshells $(n=1)$ in Japan (40) and from 
clinical samples, beef, and pork in Korea (41). It is the most prevalent ST (44/46) isolated from clinical samples and poultry in Brazil $(42,43)$ and the only ST common to human, poultry, and seabirds in Chile (44). In addition, ST11 was also reported in chicken meat $(n=76)$ in Iran (45) and beef meat in Morocco (46) and it is the common ST harboring in the genome extended-spectrum $\beta$-lactamases (ESBL) such as CTX-M-14 and CTX-M15 that have been isolated from stool and blood samples of people in Korea (47). Salmonella Enteritidis ST11 also caused pyomyositis in humans (48) and omphalitis in chicks (49). Consequently, the data indicate that $S$. Enteritidis ST11 is the most common genotype circulating in poultry and causing non-typhoidal Salmonella in humans worldwide.

Despite the limited number of $S$. Enteritidis analyzed in this study and the low discriminatory power attributed to MLST when used to type isolates from the same serovar (50), MLST could discriminate three different ST from just 10 isolates in this study suggesting that, in spite of the disadvantages noted above, MLST might be useful to type small number of $S$. Enteritidis circulating in geographical regions with limited resources.

In conclusion, we found phenotypic and genetic relationships between $S$. Enteritidis isolated from human with gastroenteritis and poultry in the Tolima region for the first time. The data constitute a preliminary evidence of the risk of an inappropriate consumption and manipulation of eggs that might be responsible for the transmission of $S$. Enteritidis to humans. It is necessary to increase consciousness in poultry producers, manipulators, salespersons, and consumers about the risks that could be prevented through education and more appropriate and rigorous surveillance systems for this pathogen.

\section{Acknowledgements}

The authors thank Dr. Luz Mari Calderón-Arateco for providing the clinical samples for Salmonella isolation.

\section{References}

1. Grimont PA, Weill FX. Antigenic formulae of the Salmonella serovars. Ninth edition. Paris, France: Institute Pasteur, WHO; 2007. p. 1-166.

2. Sanderson KE, Nair S. Taxonomy and species concepts in the genus Salmonella. In: Barrow PA, Methner U, editors. Salmonella in domestic animals. Wallingford: CABI; 2013. p. 1-19. https://doi.org/10.1079/9781845939021.0001

3. Landgridge GE, Wain J, Nair S. Invasive salmonellosis in humans. EcoSal Plus. 2012;5: 1-14. https://doi.org/10.1128/ecosalplus.8.6.2.2

4. Organización Mundial de Sanidad Animal. Manual de las pruebas de diagnóstico y de las vacunas para los animales terrestres, 2017. Chapter 2.9.8. Salmonellosis. 2010. Accessed: January 22, 2017. Available from: http://www.oie.int/fileadmin/Home/esp/Health_standards/ tahm/2.09.08_SALMONELLOSIS.pdf

5. Centers for Disease Control and Prevention. Foodborne Diseases Active Surveillance Network (FoodNet): FoodNet Surveillance Report for 2012. Atlanta, GA: U. S. Department of Health and Human Services, CDC; 2014. Accessed: January 22, 2017. Available from: https://www.colc.gov/foodnet/PDFs/2012_annual_report_508c.pdf

6. European Food Safety Authority and European Centre for Disease Prevention and Control. The European Union summary report on trends and sources of zoonoses, zoonotic agents and food-borne outbreaks in 2015. EFSA J. 2016;14:4634-231. https://doi.org/10.2903/j.efsa.2016.4634

7. Hendriksen RS, Vieira AR, Karlsmose S, Lo Fo Wong DM, Jensen AB, Wegener HC, et al. Global monitoring of Salmonella serovar distribution from the World Health Organization Global Foodborne Infections Network Country Data Bank: Results of quality assured laboratories from 2001 to 2007. Foodborne Pathog Dis. 2011;8:887-900. https://doi.org/10.1089/fpd.2010.0787 
8. Braden CR. Salmonella enterica serotype Enteritidis and eggs: A national epidemic in the United States. Clin Infect Dis. 2006;43:512-7. https://doi.org/10.1086/505973

9. Jackson BR, Griffin PM, Cole D, Walsh KA, Chai SJ. Outreak-associated Salmonella enterica Serotypes and Food Commodities, United States, 1998-2008. Emerg Infect Dis. 2013;19:1239-44. https://doi.org/10.3201/eid1908.121511

10. Majowicz SE, Musto J, Scallan E, Angulo FJ, Kirk M, O’Brien SJ, et al. International Collaboration on Enteric Disease "Burden of Illness" Studies. The global burden of nontyphoidal Salmonella gastroenteritis. Clin Infect Dis. 2010;50:882-9. https://doi.org/10.1086/650733

11. Dekker JP, Frank KM.Salmonella, Shigella, and Yersinia. Clin Lab Med. 2015;35:225-46. https://doi.org/10.1016/j.cll.2015.02.002

12. Scallan E, Hoekstra RM, Angulo FJ, Tauxe RV, Widdowson MA, Roy SL, et al. Foodborne illness acquired in the United States - major pathogens. Emerg Infect Dis. 2011;17:7-15. https://doi.org/10.3201/eid1701.P11101

13. Public Health Agency of Canada. Public Health Notice-Outbreak of Salmonella infections under investigation. March 4, 2016. Accessed: January 22, 2017. Available from: http://www. phac-aspc.gc.ca/phn-asp/2015/salmonella-infantis-eng.php

14. Public Health England. Research and Analysis, Salmonella infections (fecal specimens) in England and Wales: Laboratory reports 2016. Accessed: January 25, 2017. Available from: https://www.gov.uk/government/publications/salmonella-infections-faecal-specimens-inengland-and-wales-laboratory-reports-2016

15. European Food Safety Authority. Multi-country outbreak of Salmonella Enteritidis infections associated with consumption of eggs from Germany. EFSA J. 2014;11:646E. https://doi.org/10.2903/sp.efsa.2014.EN-646

16. European Centre for Disease Prevention and Control. Communicable disease threats report 3-September, 2016. Accessed: January 22, 2017. Available from: www.ecdc.europa.eu

17. Instituto Nacional de Salud. Boletín Epidemiológico semana 21 de 2015. Dirección de Vigilancia y Análisis del riesgo en Salud Pública. 2015. Accessed: January 25, 2017. Available from: http://www.ins.gov.co/buscador-eventos/BoletinEpidemiologico/2015\%20 Boletin\%20epidemiologico\%20semana\%2021.pdf

18. Rodríguez R, Fandiño C, Donado P, Guzmán L, Verjan N. Characterization of Salmonella from commercial egg-laying hen farms in a central region of Colombia. Avian Dis. 2015;59:59-63. https://doi.org/10.1111/j.1440-1681.2011.05632.x

19. Mogollón DC, Rodríguez VE, Verjan N. Prevalence and molecular identification of Salmonella isolated from commercialized eggs at Ibagué, Colombia. Rev Salud Anim. 2016;38:164-72.

20. Rodríguez J, Rondón I, Verjan N. Serotypes of Salmonellain broiler carcasses marketed at lbagué, Colombia. Rev Bras Ciên Avic. 2015;17:545-52. https://doi.org/10.1590/1516-635X1704545-552

21. Donado-Godoy P, Gardner I, Byrne A, Leon M, Pérez-Gutiérrez E, Ovalle MV, et al. Prevalence, risk factors, and antimicrobial resistance profiles of Salmonella from commercial broiler farms in two important poultry-producing regions of Colombia. J Food Prot. 2012;75:874-83. https://doi:10.4315/0362-028X.JFP-11-458

22. Maiden MC. Multilocus sequence typing of bacteria. Annu Rev Microbiol. 2006;60:561-88. https://doi.org/10.1146/annurev.micro.59.030804.121325

23. Pérez-Lozada M, Cabezas P, Castro-Nallar E, Crandall KA. Pathogen typing in the genomics era: MLST and the future of molecular epidemiology. Infect Genet Evol. 2013;16:38-53. https://doi.org/10.1016/j.meegid.2013.01.009

24. Thrusfield M. Veterinary epidemiology. Third edition. Ames, IO: Blackwell Publishing; 2007. p. 46-74.

25. Tindall BJ, Grimont PA, Garrity GM, Euzéby JP. Nomenclature and taxonomy of the genus Salmonella. Int J Syst Evol Microbiol. 200555:521-4. https://doi.org/10.1099/ijs.0.63580-0

26. Clinical and Laboratory Standards Institute. CLSI publishes new antimicrobial susceptibility testing standards. Wayne: CLSI; 2014.

27. Sambrook J, Russell D. Molecular cloning: A laboratory manual. Third edition. Cold Spring: Harbor Laboratory Press; 2001. p. 2100.

28. Rahn K, De Grandis A, Clarke R, McEwen A, Galán J, Ginocchio E, et al. Amplification of an InvA gene sequence of Salmonella typhimurium by polymerase chain reaction as a specific method of detection of Salmonella. Mol Cell Probes. 1992;6:271-9.

https://doi.org/10.1016/0890-8508(92)90002-F 
29. Achtman M, Wain J, Weill FX, Nair S, Zhou Z, Sangal V, et al. Multilocus sequence typing as a replacement for serotyping in Salmonella enterica. PLoS Pathog. 2012;8:e1002776. https://doi.org/10.1371/journal.ppat.1002776

30. Zhang Z, Schwartz S, Wagner L, Miller W. A greedy algorithm for aligning DNA sequences. J Comput Biol. 2000;7:203-14. https://doi.org/10.1089/10665270050081478

31. Tamura K, Stecher G, Peterson D, Filipski A, Kumar S. MEGA6: Molecular Evolutionary Genetics Analysis, version 6.0. Mol Biol Evol. 2013;30:2725-9. https://doi.org/10.1093/molbev/mst197

32. Ministerio de la Protección Social. Perfil de riesgo Salmonella spp. (no tifoideas) en pollo entero y en piezas. Bogotá: Unidad de Evaluación de Riesgos para la Inocuidad de los Alimentos, UERIA; 2011.

33. Barua H, Biswas PK, Talukder KA, Olsen KE, Christensen JP. Poultry as a possible source of non-typhoidal Salmonella enterica serovars in humans in Bangladesh. Vet Microbiol. 2014;168:372-80. https://doi.org/10.1016/j.vetmic.2013.11.020

34. Pulido M, Sánchez R, Guard J, Do Nascimento V. Presence of Salmonella Enteritidis and Salmonella Gallinarum in commercial laying hens diagnosed with fowl typhoid disease in Colombia. Avian Dis. 2014;58:165-70. https://doi.org/10.1637/10598-062613-Case.1

35. Favier GI, Lucero-Estrada CS, Lazarte-Otero V, Escudero ME. Prevalence, antimicrobial susceptibility, and molecular characterization by PCR and pulsed field gel electrophoresis (PFGE) of Salmonella spp. isolated from foods of animal origin in San Luis, Argentina. Food Control. 2013;29:49-54. https://doi.org/10.1016/j.foodcont.2012.05.056

36. Campioni F, Davis M, Medeiros MI, Falcão JP, Shah DH. MLVA typing reveals higher genetic homogeneity among $S$. Enteritidis strains isolated from food, humans and chickens in Brazil in comparison to the North American Strains. Int J Food Microbiol. 2013;162:174-81. https://doi.org/10.1016/j.ijfoodmicro.2013.01.008

37. Martelli F, Davies RH. Salmonella serovars isolated from table eggs: An overview. Food Res Int.2012;45:745-54. https://doi.org/10.1016/j.foodres.2011.03.054

38. Howard ZR, O'Bryanb CA, Crandallb PG, Rickeb SC. Salmonella Enteritidis in shell eggs: Current issues and prospects for control. Food Res Int. 2012;45:755-64. https://doi.org/10.1016/j.foodres.2011.04.030

39. Rodrigue DC, Tauxe RV, Rowe B. International increase in Salmonella Enteritidis: A new pandemic? Epidemiol Infect. 1990;105:21-7.

40. Noda T, Murakami K, Asai T, Etoh Y, Ishihara T, Kuroki T, et al. Multi-locus sequence typing of Salmonella enterica subsp. enterica serovar Enteritidis strains in Japan between 1973 and 2004. Acta Vet Scand. 2011;53:38. https://doi.org/10.1186/1751-0147-53-38

41. Ji-Yeon H, Jung-Whan C, Jun-Ho P, Moo-Sang K, Young-Hee O, In-Soo C, et al. A comparison of subtyping methods for differentiating Salmonella enteric serovar Enteritidis isolates obtained from food and human sources. Osong Public Health Res Perspect. 2013;4:27-33. https://doi.org/10.1016/j.phrp.2012.12.005

42. Campioni F, Pitondo-Silva A, Bergamini AM, Falcao JP. Comparison of four molecular methods to type Salmonella Enteritidis strains. APMIS. 2015;123:422-6. https://doi.org/10.1111/apm.12367

43. Milanez GP, Nascimento LC, Tirabassi AH, Zuanaze M, Rodrigues DP, Pereira GAG, et al. Whole-genome sequence of Salmonella enterica serovar Enteritidis phage type 4, isolated from a Brazilian poultry farm. Genome Announc. 2016;4:e00340-16. https://doi.org/10.1128/genomeA.00340-16

44. Retamal P, Fresno M, Dougnac C, Gutiérrez S, Gornall V, Vidal R, et al. Genetic and phenotypic evidence of the Salmonella enterica serotype Enteritidis human-animal interface in Chile. Front Microbiol. 2015;6:1-10. https://doi.org/10.3389/fmicb.2015.00464

45. Ghaderi R, Tadayon K, Khaki P, Mosavari N. Iranian clonal population of Salmonella enterica serovar Enteritidis, characterized by multi-locus sequence typing (MLST) method. Iran J Microbiol. 2015;7:251-9.

46. Murgia M, Bouchrif B, Timinouni M, Al-Qahtani A, Al-Ahdal MN, Cappuccinelli P, et al. Antibiotic resistance determinants and genetic analysis of Salmonella enterica isolated from food in Morocco. Int J Food Microbiol. 2015;215:31-9. https://doi.org/10.1016/j.ijfoodmicro.2015.08.003

47. Kim Y, Baea IK, Jeong SH, Leeb CH, Lee HK, Ahnd J, et al. Occurrence of IncFIl plasmids carrying the blaCTX-M-15 gene in Salmonella enterica serovar Enteritidis sequence type 11 in Korea. Diagn Microbiol Infect Dis. 2011;71:171-3. https://doi.org/10.1016/.diagmicrobio.2011.05.004 
48. Hwang JH, Shin GW, Lee CS. Community-onset pyomyositis caused by a Salmonella enterica serovar Enteritidis sequence type 11 strain producing CTX-M-15 extended-spectrum lactamase. J Clin Microbiol. 2015;53:1439-41. https://doi.org/10.1128/JCM.03097-14

49. Jones-Dias D, Clemente L, Egas C, Froufe H, Sampaio DA, Vieira L, et al. Salmonella enteritidis isolate harboring multiple efflux pumps and pathogenicity factors, shows absence of o antigen polymerase gene. Front Microbiol. 2016;7:1130. https://doi.org/10.3389/fmicb.2016.01130

50. Barco L, BarrucciF, Elmerdahl JO, Ricci A. Salmonella source attribution based on microbial subtyping. Int J Food Microbiol. 2013;163:193-203.

https://doi.org/10.1016/j.ijfoodmicro.2013.03.005 